\title{
FIRST REPORT ON Cryptococcus neoformans IN PIGEON EXCRETA FROM PUBLIC AND RESIDENTIAL LOCATIONS IN THE METROPOLITAN AREA OF CUIABÁ, STATE OF MATO GROSSO, BRAZIL
}

Doracilde Terumi TAKAHARA(1), Márcia dos Santos LAZÉRA(2), Bodo WANKE(2), Luciana TRILLES(2), Valéria DUTRA(3), Daphine Ariadne Jesus de PAULA(3), Luciano NAKAZATO(3), Mariana Caselli ANZAI(1), Diniz Pereira LEITE JÚNIOR(1), Claudete Rodrigues PAULA(4) \& Rosane Christine HAHN(1)

\begin{abstract}
SUMMARY
Cryptococcosis is a severe systemic mycosis caused by two species of Cryptococcus that affect humans and animals: $C$. neoformans and $C$. gattii. Cosmopolitan and emergent, the mycosis results from the interaction between a susceptible host and the environment. The occurrence of $C$. neoformans was evaluated in 122 samples of dried pigeon excreta collected in 49 locations in the City of Cuiabá, State of Mato Grosso, Brazil, including public squares $(n=5)$, churches $(n=4)$, educational institutions $(n=3)$, health units $(n=8)$, open areas covered with asbestos $(n=4)$, residences $(n=23)$, factory $(n=1)$ and a prison $(n=1)$. Samples collected from July to December of 2010 were seeded on Niger seed agar (NSA). Dark brown colonies were identified by urease test, carbon source assimilation tests and canavanine-glycine-bromothymol blue medium. Polymerase chain reaction primer pairs specific for $C$. neoformans were also used for identification. Cryptococcus neoformans associated to pigeon excreta was isolated from eight (6.6\%) samples corresponding to six (12.2\%) locations. Cryptococcus neoformans was isolated from urban areas, predominantly in residences, constituting a risk of acquiring the disease by immunocompromised and immunocompetent individuals.
\end{abstract}

KEYWORDS: Cryptococcus neoformans; Pigeon excreta; Urban environment; State of Mato Grosso.

\section{INTRODUCTION}

Although cryptococcosis has been studied since 1894, over the past 40 years many important advances have been achieved regarding taxonomy, epidemiology, capsular structure, virulence factors, serotypes and specific genotypes ${ }^{25}$. In Brazil, reports have been registered in most states $^{11,16,23,29,34,39}$, but in the State of Mato Grosso little research has been conducted in relation to clinical and environmental isolates of the agents of cryptococcosis. The first description of these microorganisms in HIVpositive patients in Mato Grosso was reported by FAVALESSA et al., who detected 26 Cryptococcus neoformans and 10 Cryptococcus gattii isolates in distinct clinical materials from seropositive and seronegative patients ${ }^{10}$.

The genus Cryptococcus comprises more than 38 species, two of which are considered potentially pathogenic: Cryptococcus neoformans and $C$. gattii ${ }^{17,18,20}$. Although both are found worldwide, their main ecological niches present some differences: Cryptococcus neoformans is most commonly isolated from pigeon droppings, while $C$. gattii is more frequently isolated from decaying wood and soil ${ }^{14,24,25}$.

The presence of Cryptococus neoformans in soil and old dried pigeon excreta has been widely studied in several countries ${ }^{7,8}$. Poultry manure is considered a natural substrate for C. neoformans. Pigeons can even carry it on their beaks, feathers and legs, as well as presenting colonization by this agent on the crop. They act as dispersers in the environment, generating a source of infection for humans. Regarding the primary habitat of $C$. neoformans, species of plants and aged woods can be considered locations where the yeasts may naturally develop their sexual state ${ }^{32}$.

Considering the complete lack of data reported in the literature to date, the present study aimed to evaluate the possible environmental distribution of $C$. neoformans in public places (churches, squares, educational institutions, prisons, factories and health facilities) and residences within the City of Cuiabá and the neighbor metropolitan area.

\section{MATERIAL AND METHODS}

Study periods and locations: The samples were collected between July and December of 2010 in the metropolitan area of Cuiabá.

Mato Grosso is located in the Midwest region of Brazil. The state occupies an area of $903,357 \mathrm{~km}^{2}$, being the third largest from Brazil and it is the only one to have three characteristic biomes, Pantanal 


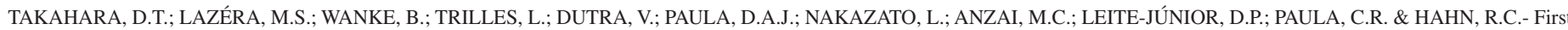
report on Cryptococcus neoformans in pigeon excreta from public and residential locations in the metropolitan area of Cuiabá, State of Mato Grosso, Brazil. Rev. Inst. Med. Trop. Sao Paulo, 55(6): 371-6, 2013
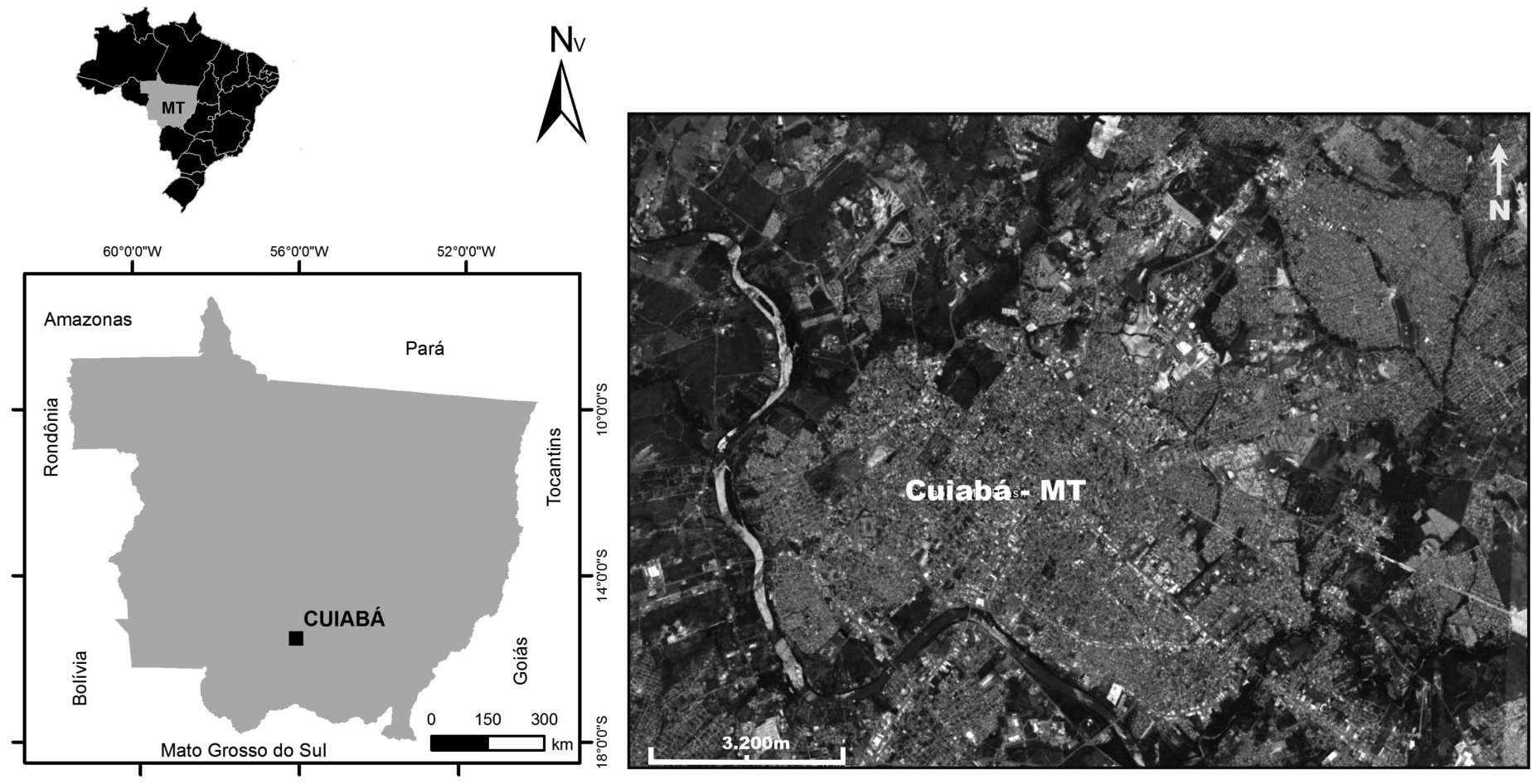

Fig. 1 - Location of the City of Cuiabá, State of Mato Grosso, Brazil.

(marshland), Cerrado (Brazilian savanna) and Amazon. Its capital is the City of Cuiabá, which has about 551,000 inhabitants. In its territory is situated the geodesic center of South America, at $15^{\circ} 35^{\prime} 56^{\prime \prime}$ South and $56^{\circ} 06^{\prime} 05^{\prime \prime}$ West (Fig. 1).

The climate is characterized by a mean annual rainfall of $1,469.4$ $\mathrm{mm}$ and average annual temperature of 24 to $26^{\circ} \mathrm{C}$. Despite unequally distributed, the region is well supplied with rain and seasonality is typically tropical, with maximal temperatures in summer and minimal in winter. Over $70 \%$ of the total rainfall accumulated during the period of November to March. The winters are excessively dry, due to very scarce rainfall ${ }^{35}$. The average temperature during the collecting period was $27^{\circ} \mathrm{C}$ (July to December 2010), with maximal that reached $40{ }^{\circ} \mathrm{C}$ for several times in August, September and October ${ }^{15}$.

The sites selected were characterized as follows: five public squares, four churches, three educational institutions, eight public health units, four open areas covered with asbestos, 23 residences, one factory and one prison.

Inclusion criteria: At all the sites selected, aspects related to the excreta collected were evaluated according to the following parameters: excreta presenting a dried aspect; deposited on the surfaces of public or residential environments; the presence of pigeons close to the excreta; the presence of chicks or nests; and sufficient quantity for posterior weighing (> one gram) and analysis.

Sample processing: Following homogenization, $1 \mathrm{~g}$ of each sample was suspended in $50 \mathrm{~mL}$ of sterile physiological saline with $0.4 \mathrm{~g} / \mathrm{L}$ chloramphenicol, shaken for five min and allowed to settle for $30 \mathrm{~min}$.
The supernatant was aspirated, inoculated onto Niger seed agar (NSA) medium $(0.1 \mathrm{~mL}$ of supernatant per plate, 10 plates per sample), incubated at room temperature $\left(25^{\circ} \mathrm{C}\right.$ to $\left.27^{\circ} \mathrm{C}\right)$ and observed for five to seven days.

Yeast colonies on NSA were selected by observing the shiny, smooth, and dark brown colonies (due to melanin production). The brown colonies were sub-cultivated onto Sabouraud (Merck) medium for urease test and other biochemical tests as well microscopic analysis with India ink to visualize the capsule ${ }^{21,22}$ For the biochemical tests, auxanogram technique was used, in which the assimilation of eleven carbon sources (dextrose, lactose, maltose, sucrose, inositol, galactose, cellobiose, melezitose, melibiose, rhamnose and erythritol) and two nitrogen sources (peptone and potassium nitrate $)^{18,22}$ were used to identify the cryptococcal isolates.

The dark brown colonies were also sub-cultivated onto NSA medium which is recommended to confirm phenoloxidase activity ${ }^{11}$. After passage through NSA medium, dark brown colonies were seeded on CGB medium (L-canavanine glycine bromothymol blue) for species identification ${ }^{19}$ No alteration in the yellow-green original color of the CGB medium confirms C. neoformans.

For molecular identification of the cryptococcal isolates, the protocol described by POETA et al. ${ }^{33}$ was used, with modifications, for DNA extraction. Yeast cells were suspended in $0.5 \mathrm{~mL}$ TENTS $[10 \mathrm{mM}$, Tris $\mathrm{pH} 8.0,5 \%$ sodium dodecyl sulfate (SDS)]. Then, $0.5 \mathrm{~g}$ of $0.5-\mathrm{mm}$ glass beads were added and boiled at $100{ }^{\circ} \mathrm{C}$ for $10 \mathrm{~min}$. It was then added 0.5 $\mathrm{mL}$ of phenol: chloroform and samples were vortexed for two min. After centrifugation for $10 \mathrm{~min}$ in a microfuge at $14,500 \mathrm{x} g$, the aqueous phase was transferred to a tube with one volume of isopropanol and $0.3 \mathrm{M}$ of sodium acetate was added, and samples were placed at $-20{ }^{\circ} \mathrm{C}$ overnight. 


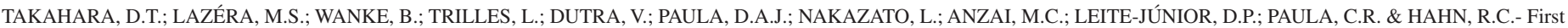

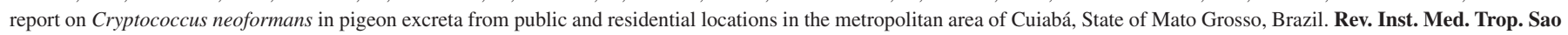
Paulo, 55(6): 371-6, 2013.

DNA collected was precipitated, washed with $70 \%$ ethanol, re-suspended in $50 \mu \mathrm{L}$ of ultrapure water and stored at $-20^{\circ} \mathrm{C}$.

To confirm the species of the isolates, pairs of primers CNA70A (5'-ATTGCGTCCATGTTACGTGGC-3') and CNA70S (5'-ATTGCGTCCACCAAGGAGCTC-3 ') specific for C. neoformans were used, resulting in amplification products of $695 \mathrm{bp}^{2,13}$.

\section{RESULTS}

All the brown colonies isolated on NSA medium were encapsulated yeast forms, and have been observed in microscopy with India Ink. All were thermotolerant to $37^{\circ} \mathrm{C}$, urease-producing and inhibited by cycloheximide. In Canavanine-glycine-bromothimol blue medium (CGB) didn't have color change and this confirmed specie C. neoformans, as well as the assimilation of carbohydrates (glucose, maltose, sucrose, galactose, cellobiose, inositol, xylose, raffinose, trehalose, dulcitol) and no nitrate assimilation. All colonies isolated was confirmed by PCR (Polymerase Chain Reaction) from the use of specific primers. Further analysis should be performed to investigate the molecular types of these isolates.

One hundred and twenty-two dry pigeon excreta samples were chosen at random from different locations (Table 1).

The presence of excreta was detected in the eight groups evaluated. However, considering the squares, the presence of excreta was only observed in four of the eleven surveyed. Similarly, in four of the ten churches and three of the five schools the same fact was observed, concomitant presence of pigeons and excreta. According to the isolation of C. neoformans, it was possible to determine that these yeasts were mostly detected in the pigeon excreta collected from the residences assessed.

Regarding the different groups evaluated, $C$. neoformans was detected in one of the four churches, specifically in the tower, where the presence of both pigeons and excreta were observed. C. neoformans was isolated in one of the three educational institutions inhabited by pigeons where excreta were also observed. Isolates of $C$. neoformans were similarly identified in samples from four of the 23 residences evaluated.

The presence of pigeon excreta was observed in $49(78 \%)$ of the 63 sites visited. The presence of these substrata according to the different sites is presented in Table 1.

Isolation of C. neoformans was obtained from six (12.2\%) of the 49 sites analyzed, where eight $(6.6 \%)$ out of 122 samples of dried pigeon excreta collected were positive.

Two samples collected from the church were positive for $C$. neoformans, eight colonies were detected. In the educational institution, $C$. neoformans was detected in only one of the 13 samples analyzed and in this sample, four colonies were detected. Regarding the residences, five samples positive for $C$. neoformans were obtained and 60 colonies were detected.

The identification of C. neoformans isolates was confirmed by PCR using specific primers (Fig. 2).

\section{DISCUSSION}

The deposition of pigeon excreta (Columba livia) in public places can serve as a source of infectious agents of importance for public health, such as $C$. neoformans. In this study, certain facts observed during sample collection deserve attention: the amount of excreta obtained was variable, in that frequent cleaning was observed in several of the public spaces evaluated. Thus, despite the presence of pigeons, the presence of excreta was not verified at all the sites selected.

Furthermore, in the majority of the sites visited, there were no mechanical barriers to prevent access by pigeons, a resource currently used to hinder the approach of pigeons to windows, air conditioning units and other physical barriers.

Table 1

Types and number of sites investigated (Groups) and positivity (\%) associated with the presence of Cryptococcus neoformans in pigeon excreta of environments in the Cuiabá City, State of Mato Grosso, Brazil

\begin{tabular}{|c|c|c|c|c|c|c|}
\hline \multirow{3}{*}{ Groups/type of location } & \multirow{3}{*}{ Number } & \multirow{3}{*}{$\begin{array}{c}\text { Presence of } \\
\text { excreta }\end{array}$} & \multirow{3}{*}{ Sample (n) } & \multirow{3}{*}{$\begin{array}{l}\text { Sample } \\
\text { positive }\end{array}$} & \multicolumn{2}{|c|}{ Isolation } \\
\hline & & & & & absolute & relative \\
\hline & & & & & $\mathrm{n}$ & $\%$ \\
\hline Group I: squares & 11 & 5 & 12 & 0 & 0 & 0.0 \\
\hline Group II: churches & 10 & 4 & 13 & 2 & $1 / 4$ & 25.0 \\
\hline Group III: educational institutions & 5 & 3 & 13 & 1 & $1 / 3$ & 33.0 \\
\hline Group IV: health units & 8 & 8 & 20 & 0 & 0 & 0.0 \\
\hline Group V: open areas* & 4 & 4 & 11 & 0 & 0 & 0.0 \\
\hline Group VI: residences & 23 & 23 & 44 & 5 & $4 / 23$ & 17.0 \\
\hline Group VII: factories & 1 & 1 & 3 & 0 & 0 & 0.0 \\
\hline Group VIII: prisons & 1 & 1 & 6 & 0 & 0 & 0.0 \\
\hline Total & 63 & $49(78 \%)$ & 122 & $8(6.6 \%)$ & $6 / 49$ & 12.2 \\
\hline
\end{tabular}

*with asbestos covering. 


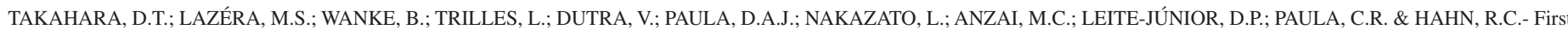
report on Cryptococcus neoformans in pigeon excreta from public and residential locations in the metropolitan area of Cuiabá, State of Mato Grosso, Brazil. Rev. Inst. Med. Trop. Sao Paulo, 55(6): 371-6, 2013

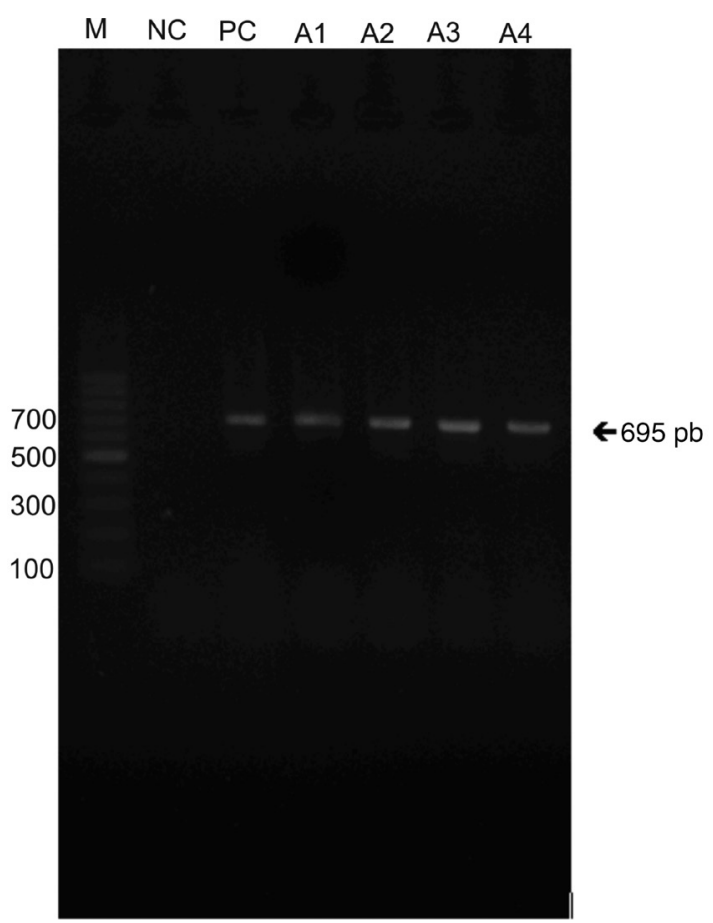

Fig. 2 - PCR amplification of Cryptococcus neoformans: M, 100 pb DNA ladder, 1 negative control (NC), 1 positive control (PC) and sample isolates A1 (church), A2 (educational institution), A3 (residence 1) and A4 (residence 2).

The isolation of virulent strains of the fungus from soil samples was first reported by SILVA \& CAPUANO ${ }^{37}$ in Brazil as early as 1960. MACHADO et al. ${ }^{27}$ also reported recovering this fungus from the soil in an attempt to correlate the clinical-epidemiological history of patients suffering from cryptococcosis in the Santa Casa of Porto Alegre, in the State of Rio Grande do Sul (RS), Brazil.

In this study, only samples of pigeon excreta were collected, soil samples were not included. However, when considering studies that examined samples of pigeon excreta, positivity rates for the isolation of the fungus in Brazil ranged from 4.3 to $31.3 \%$ 3,6,9,13,16,23,27,28,29,31,34,37,39. The findings of this study show a positivity rate of $12 \%$ for $C$. neoformans, values that are compatible with the rates of isolation in Brazil previously reported in the literature. Most of the total samples analyzed (44/122) were from residences, sites which presented expressive positivity (17\%). This finding may represent a risk for the acquisition of cryptococcosis, since in several of the evaluated residences the habit of feeding pigeons by residents was frequently observed, luring them and indirectly encouraging them to reproduce. Food scraps were also found in these places, reflecting poor hygiene care in the common areas of residential estates.

Ten churches were visited and the presence of excreta was investigated in four, though positivity for $C$. neoformans was demonstrated only in one. BARONI et al. ${ }^{3}$ also evaluated the presence of $C$. neoformans in ten churches in the City of Rio de Janeiro and C. neoformans was found in every church selected and was present in $37.8 \%$ of 219 pigeon dropping samples. Samples of excreta were obtained, in addition to air samples in church towers and from the surrounding areas. It is known that high summer temperatures can inhibit the growth of $C$. neoformans, possibly due to inactivation of the yeast ${ }^{36,40}$. Cuiabá is known for its high temperatures, a factor that should be considered in relation to the low rates of detection of $C$. neoformans in pigeon excreta at the sites evaluated.

According to $\mathrm{BULMER}^{4}$, the problem is the long viability of $C$. neoformans in dried excreta, about two years. Based on this information, old buildings and towers of old churches can be considered potential sources for $C$. neoformans and should be periodically evaluated by public health authorities. In Cuiabá, most churches are fairly old (over 50 years-old) and are considered historical monuments of the city, which completed 292 years in 2011.

Uninfected pigeon excreta can become infected when exposed to air containing aerosolized cells of $C$. neoformans ${ }^{5}$. Considering all the locations where pigeon excreta might be deposited within the urban areas of Cuiabá, the aerial dispersion of cryptococcal propagules from the positive sites to the surroundings is probably occurring. The positivity $(12 \%)$ rate for the isolation of $C$. neoformans from pigeon excreta detected in this study is in agreement with the values obtained by LOPEZ-MARTINEZ et al. ${ }^{26}$, who analyzed 711 samples from numerous environmental sources in Mexico City, including bird droppings, fruits and vegetables. They reported the presence of $C$. neoformans in $9.5 \%$ of excreta samples, $9.5 \%$ in fruits and $4.2 \%$ vegetables. In contrast, in another study in Bogota (Colombia), 480 samples of debris from trees and 89 excreta samples were investigated. Among the plant samples, $99 \%$ were characterized as C. gattii and $1 \%$ as C. neoformans, while in the excreta samples, only C. neoformans was isolated ${ }^{12}$.

Considering the public squares in the present study, the findings in Cuiabá contrast with those obtained in Porto Alegre, Rio Grande do Sul State, by REOLON et al. ${ }^{34}$ They affirmed that in all five squares in which the investigation of yeasts of the genus Cryptococcus was conducted, a total of 88 samples, positivity was obtained in all 88 (100\%) samples. In our study, 11 squares were evaluated, but it was not possible to isolate yeasts of the genus Cryptococcus, despite the presence of excreta in five of the squares. The authors who conducted the study in Porto Alegre did not mention the period or season in which the materials were collected, making it virtually impossible to compare the factors that could interfere with the isolation of yeasts in cities with very different bioclimatic conditions, such as Cuiabá and Porto Alegre.

In the City of Pelotas, Rio Grande do Sul State, FARIA et al. ${ }^{9}$ evaluated 70 environments, including squares $(n=1)$, historic buildings $(n=8)$, church towers $(n=1)$, rice mills and warehouses $(n=7)$ and outdoor locations $(n=9)$. Considering all these sites, the isolation of C. neoformans was verified in $26.9 \%(\mathrm{n}=7 / 26)$. Among the 14 squares evaluated in Pelotas, only one had a mean quantity excreta from which $C$. neoformans was isolated. The City of Pelotas has no extreme temperatures and relative humidity is high. This contrasts with the bioclimatic conditions of Cuiabá, where temperatures in August, September and October, rise considerably and the relative humidity remains extremely low, reaching critical levels. Sun light exposure associated with the climate of Cuiaba may be critical for the survival of $C$. neoformans in open areas of the city. Moreover the agent was mainly isolated from protected places in Cuiabá, such as an educational institution, a church and four residences. These findings reveal the risk of exposure for immunosuppressed and even immunocompetent individuals in daily activities or living in these microenvironments. Measures are required to 


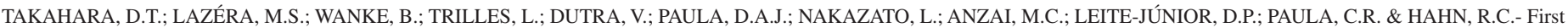

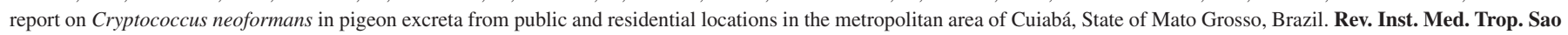
Paulo, 55(6): 371-6, 2013.

reduce the number of birds through the maintenance of adequate hygiene, aeration, lighting and ventilation ${ }^{1,11}$. Simply performing adequate cleaning of such environments could be effective, as well as not offering food to pigeons, particularly in residential areas.

\section{RESUMO}

\section{Primeiro registro de Cryptococcus neoformans em excretas de pombos provenientes de locais públicos e residenciais de área metropolitana de Cuiabá, Estado do Mato Grosso, Brasil}

A criptococose é micose sistêmica potencialmente grave causada por duas espécies do gênero Cryptococcus que acometem tanto homens como animais: Cryptococcus neoformans e $C$. gattii. São infecções cosmopolitas e emergentes, resultantes da interação do hospedeiro - humano e animal versus meio ambiente. A proposta deste trabalho foi avaliar a ocorrência de C. neoformans em 122 amostras de excretas secas de pombos coletadas em 49 locais na cidade de Cuiabá, Estado do Mato Grosso, Brasil, incluindo: praças públicas $(n=5)$, igrejas $(n=4)$, instituições de ensino $(\mathrm{n}=3)$, unidades de saúde $(\mathrm{n}=8)$, áreas abertas exibindo cobertura de amianto $(n=4)$, conjuntos residenciais domiciliares $(n=23)$, uma fábrica $(n=1)$ e um presídio $(n=1)$. Semeadura de suspensão de amostras em meio ágar niger (NSA), identificação fenotípica por provas bioquímicas e teste em meio de canavanina-glicina-azul de bromotimol, das colônias isoladas com pigmentação marrom escura. Foi também utilizada a técnica da reação em cadeia da polimerase com pares de iniciadores específicos para identificação de C. neoformans. As amostras foram coletadas de julho a dezembro de 2010. Cryptococcus neoformans foi isolado em oito $(6,6 \%)$ de 122 amostras correspondendo a seis (12,2\%) dos 49 sítios analisados. Cryptococcus neoformans associado a excretas de pombos ocorre em áreas de Cuiabá, predominando em residências nas amostras analisadas, constituindo fator de risco potencial para aquisição da doença tanto para indivíduos imunocomprometidos como imunocompetentes.

\section{ACKNOWLEDGMENTS}

Financial support for this study was provided by FAPEMAT Fundação de Amparo à Pesquisa no Estado de Mato Grosso [State of Mato Grosso Foundation for the Support of Science].

\section{REFERENCES}

1. Abegg MA, Cella FL, Faganello J, Valente P, Schrank A, Vainstein MH. Cryptococcus neoformans and Cryptococcus gattii isolated from the excreta of psittaciformes in a southern Brazilian zoological garden. Mycopathologia. 2006;161:83-91

2. Aoki FH, Imai T, Tanaka R, Mikami Y, Taguchi H, Nishimura NF, et al. New PCR primer pairs specific for Cryptococcus neoformans serotype A or B prepared on the basis of random amplified polymorphic DNA fingerprint pattern analyses. J Clin Microbiol. 1999;37:315-20.

3. Baroni FA, Paula CR, Silva EG, Viani FC, Rivera ING, Oliveira MTB, et al. Cryptococcus neoformans strains isolated from church towers in Rio de Janeiro City, RJ, Brazil. Rev Inst Med Trop Sao Paulo. 2006;48:71-5.

4. Bulmer GS. Twenty-five years with Cryptococcus neoformans. Mycopathologia. 1990;109:111-22.

5. Casadevall A, Perfect JR. Cryptococcus neoformans. Washington: American Society for Microbiology Press; 1998
6. Casali AK, Goulart L, Rosa e Silva LK, Ribeiro AM, Almeida AA, et al. Molecular typing of clinical and environmental Cryptococcus neoformans isolates in the Brazilian State Rio Grande do Sul. FEMS Yeast Res. 2003;3:405-15.

7. Currie BP, Freundlich LF, Casadevall A. Restriction fragment length polymorphism analysis of Cryptococcus neoformans isolates from environmental (pigeon excreta) and clinical sources in New York City. J Clin Microbiol. 1994;32:1188-92.

8. Emmons CW. Saprophytic sources of Cryptococcus neoformans associated with the pigeon (Columba livia). Amer J Hyg. 1955;62:227-32.

9. Faria RO, Nascente PS, Meinerz ARM, Cleff MB, Antunes TA, Silveira ES, et al. Ocorrência de Cryptococcus neoformans em excretas de pombos na cidade de Pelotas, Estado do Rio Grande do Sul. Rev Soc Bras Med Trop. 2010;43:198-200.

10. Favalessa OC, Ribeiro LC, Tadano T, Fontes CJF, Dias FB, Coelho BP, et al. Primeira descrição da caracterização fenotípica e susceptibilidade in vitro a drogas de leveduras do gênero Cryptococcus spp isoladas de pacientes HIV positivos e negativos, Estado de Mato Grosso. Rev Soc Bras Med Trop. 2009;42:661-5.

11. Filiú WF, Wanke B, Agüena SM, Vilela VO, Macedo RC, Lazéra MS. Cativeiro de aves como fonte de Cryptococcus neoformans na cidade de Campo Grande, Mato Grosso do Sul, Brasil. Rev Soc Bras Med Trop. 2002;35:591-5.

12. Granados DP, Castañeda E. Isolation and characterization of Cryptococcus neoformans varieties recovered from natural sources in Bogotá, Colombia, and study of ecological conditions in the area. Microb Ecol. 2005;49:282-90.

13. Horta JA, Staats CC, Casali AK, Ribeiro AM, Schrank IS, Schrank A, et al. Epidemiological aspects of clinical and environmental Cryptococcus neoformans isolates in the Brazilian state Rio Grande do Sul. Med Mycol. 2002;40:565-71.

14. Idnurm A, Bahn Y, Nielsen K, Lin X, Fraser JA, Heitman J. Deciphering the model pathogenic fungus Cryptococcus neoformans. Nat Rev Microbiol. 2005;3:753-64.

15. Instituto Nacional de Meteorologia (INMET) [Internet]. Brasilia, DF, Brasil: INMET [Updated 2011 January 2001; Cited 2011 October 29] Available from: http://www. inmet.gov.br/html/observacoes.php?/

16. Kobayashi CC, Souza LK, Fernandes OF, Brito SC, Silva AC, Sousa ED, et al Characterization of Cryptococcus neoformans isolated from urban environmenta sources in Goiânia, Goiás, Brazil. Rev Inst Med Trop Sao Paulo. 2005;47:203-7.

17. Kon AS, Grumach AS, Colombo AL, Penalva ACO, Wanke B, Telles FQ, et al. Consenso em criptococose - 2008. Rev Soc Bras Med Trop. 2008;41:524-44.

18. Kwon-Chung KJ, Bennet JE. Cryptococcosis. In: Kwon-Chung KJ, Bennet JE, editors Medical Mycology. Philadelphia: Lea \& Febiger; 1992. p. 426-36.

19. Kwon-Chung KJ, Bennet JE. Culture media and reagents. In: Kwon-Chung KJ, Bennet JE, editors. Medical Mycology. Appendix B. Philadelphia: Lea \& Febiger 1992. p. $816-26$.

20. Kwon-Chung KJ, Boekhout T, Fell TJ, Diaz M. Proposal to conserve the name Cryptococcus gattii against $C$. hondurianus and C. bacillisporus (Basidiomycota Hymenomycetes, Tremellomycetidae). Taxon. 2002;51:804-6.

21. Kwon-Chung KJ, Polacheck I, Bennett JE. Improved diagnostic medium for separation of Cryptococcus neoformans var. neoformans (serotypes A and D) and Cryptococcus neoformans var. gattii (serotypes B and C). J Clin Microbiol. 1982;15:535-7.

22. Lacaz CS, Porto E, Martins JEC, Heins-Vaccari EM, Mello NT. Criptococcose. In Lacaz CS, Porto E, Martins JEC, Heins-Vaccari EM, Mello NT, editors. Tratado de Micologia Médica. $9^{\text {th }}$. ed. São Paulo: Sarvier; 2002. p. 416-40.

23. Lazéra MS, Wanke B, Nishikawa MM. Isolation of both varieties of Cryptococcus neoformans var. neoformans from saprophytic sources in the city of Rio de Janeiro, Brazil. J Med Vet Mycol. 1993;31:449-54. 


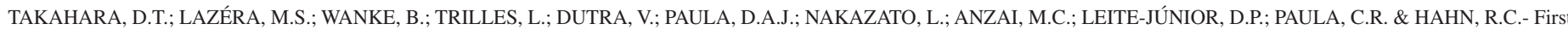
report on Cryptococcus neoformans in pigeon excreta from public and residential locations in the metropolitan area of Cuiabá, State of Mato Grosso, Brazil. Rev. Inst. Med. Trop. Sao Paulo, 55(6): 371-6, 2013.

24. Levitz SM. The ecology of Cryptococcus neoformans and the epidemiology of cryptococcosis. Rev Infect Dis. 1991;13:1163-9.

25. Lin X, Heitman J. The biology of the Cryptococcus neoformans species complex. Ann Rev Microbiol. 2006;8:69-105.

26. López-Martínez R, Castañón-Olivares LR. Isolation of Cryptococcus neoformans var. neoformans from bird droppings, fruits and vegetables in Mexico City. Mycopathologia. 1995;129:25-8.

27. Machado CC, Amaral AA, Severo LC. Cryptococcus neoformans var. neoformans isolado do solo. Rev Inst Med Trop Sao Paulo. 1993;35:77-9.

28. Montenegro H, Paula CR. Environmental isolation of Cryptococcus neoformans var. gattii and C. neoformans var. neoformans in the city of São Paulo, Brazil. Med Mycol. 2000;38:385-90

29. Melo NT, Nigro RC, Pereira AD, Huggins D, Lacaz CS. Isolamento de Cryptococcus neoformans de fezes de pombos, do solo e ninhos de pombos. Rev Bras Med. 1987;44:6-9.

30. Pappalardo MC, Melhem MS. Cryptococcosis: a review of the Brazilian experience for the disease. Rev Inst Med Trop Sao Paulo. 2003;45:299-305.

31. Passoni LF, Wanke B, Nishikawa MM, Lazéra MS. Cryptococcus neoformans isolated from human dwellings in Rio de Janeiro, Brazil: an analysis of the domestic environmental of AIDS patients with and without cryptococcosis. Med Mycol. 1998;36:305-11.

32. Passoni LF. Wood, animals and human beings as reservoirs for human Cryptococcus neoformans infection. Rev Iberoam Micol. 1999;16:77-81.
33. Poeta MD, Toffaletti DL, Rude TH, Dykstra CC, Heitman J, Perfect JR. Topoisomerase I is essential in Cryptococcus neoformans: role in pathobiology and as an antifungal target. Genetics. 1999;152:167-78.

34. Reolon A, Perez LRR, Mezzari A. Prevalência de Cryptococcus neoformans nos pombos urbanos da cidade de Porto Alegre, Rio Grande do Sul, Brasil. J Bras Patol Med Lab. 2004;40:293-8.

35. Rolim GS, Camargo MBP, Lania DG, Moraes JFL. Classificação climática de Köppen e Thornthwaite e sua aplicabilidade na determinação de zonas agroclimáticas para o Estado de São Paulo. Bragantia. 2007;66:711-20.

36. Rosario I, Hermoso-de-Mendonza M, Déniz S, Soro G, Álamo I, Acosta B. Isolation of Cryptococcus species including C. neformans from cloaca of pigeons. Mycoses. 2005;48:421-4.

37. Silva JO, Capuano DM. Ocorrência de Cryptococcus spp e de parasitas de interesse em saúde pública, no excreta de pombos na cidade de Ribeirão Preto, SP, Brasil. Rev Inst Adolfo Lutz. 2008;67:137-41.

38. Silva ME, Paula LA. Isolamento de Cryptococcus neoformans de excrementos e ninhos de pombos (Columba livia) em Salvador, Bahia. Rev Inst Med Trop Sao Paulo. 1963;5:9-11.

39. Silva ME. Ocorrência de Cryptoccocus neoformans e Microsporum gypseum em solos da Bahia, Brasil. Bol Fund Gonçalo Moniz. 1960;17:1-14.

40. Sorrell TC, Ellis DH. Ecology of Cryptococcus neoformans. Rev Iberoam Micol. 1997; 14:42-3.

Received: 10 December 2012

Accepted: 4 April 2013 